\title{
Attitudes towards English in Cuban Higher Education. Recent Developments and Challenges
}

\section{Van Splunder, Frank ${ }^{a}$ and Dávila Pérez, Geisa ${ }^{b}$}

${ }^{a}$ Linguapolis, University of Antwerp, Belgium, ${ }^{\mathrm{b}}$ Language Department, Universidad de Oriente, Cuba.

\begin{abstract}
English is used as a lingua franca in an increasing number of domains. In higher education, English has become prominent as the language of course materials, scientific publications, research as well as teaching, a trend which is particularly noticeable in Europe. In Latin America, however, the surge of English is relatively recent, and within Latin America, Cuba is an interesting case. Whereas learning English was not encouraged in the 1980s, in today's Cuba English has gained importance, and learning and teaching English has become a priority.

The current research explores how Cuban students and lecturers of two different fields (English and Engineering) perceive the growing importance of English in today's higher education in Cuba. Data were collected by means of a questionnaire conducted at Universidad de Oriente, Santiago de Cuba. The results reveal a positive attitude towards English, which most participants perceive as very important for their career prospects. On the other hand, it was found that most respondents overrate their ability to communicate in English. Moreover, they are not acquainted with the Common European Framework of Reference for Languages (CEFR), even though the Cuban Ministry of Higher Education has accepted the CEFR as its official standard.
\end{abstract}

Keywords: attitudes; English language; higher education; Cuba; CEFR 


\section{Introduction}

English is the language of globalization (Crystal, 2003; Dewey, 2007; Pennycook, 2010). This is mainly due to the worldwide dominance of the United States since World War II and the resulting use of English as a lingua franca in an increasing number of domains, including the economy, politics, and culture (Fishman, 2006). In higher education, English has become prominent as the language of manuals and course materials, scientific publications, research, as well as teaching, a trend which is particularly noticeable in Europe (Wächter, 2014). In Latin America, however, the surge of English is relatively recent, and the level of English tends to be generally low (English Proficiency Index, 2017). Within Latin America, Cuba takes a mid-position on the 2017 English Proficiency Index with a score of 50.83; i.e. 'low proficiency'.

Cuba is a very interesting case as its relations with the United States have been strained since the 1959 Revolution. It was not until 2015 that diplomatic relations between both countries were resumed officially. In a groundbreaking move after more than half a century of estrangement, President Obama aimed to normalize relations between both countries, and Secretary of State Kerry presided over the official reopening of the US Embassy in Cuba on 24 August 2015. While Cuba was awash with hope that relations between both countries were eventually back to normal, the new administration appears to have dashed this hope as President Trump tightened the economic embargo on Cuba and released new, restrictive travel rules in 2017 (Alzugaray, 2017; Pope \& Finn, 2017; Dembicz, 2017; Grabendorff, 2017).

Consequently, learning and teaching English in Cuba should be understood in the context of this fraught relationship with its dominant neighbour. Whereas in the 1980s, learning English was not encouraged in Cuba and it was even seen as 'supporting the Americans' (Pignatelli, 2017), in today's Cuba English has been gaining importance, and the learning, teaching and testing of English has become a priority. Thus, the Cuban Ministry of Higher Education (Ministerio de Educación Superior, henceforth MES) stresses the importance of foreign languages - English in particular - to be able to fully participate in a globalizing world (MES, 2013).

Following this new policy, the Ministry adopted the B1+ level; i.e. 'Independent User' according to the CEFR (Council of Europe, 2001) as a requirement for graduation, and students have up to four years to acquire the necessary language skills, both written and orally. In order to acquire these skills, students can attend English language courses, make use of academic services in English, or manage their learning independently. Language centres (Centros de Idiomas) as well as self-access centres (Centros de Auto-acceso) are set up to meet the needs of training in English. 
The underlying assumption is that globalization necessitates English, and therefore the Cuban Ministry introduced a paradigmatic shift in the teaching and learning of English. Whereas during the period 1960-1982 the focus was on reading skills in a broad sense, and then, between 1983 and 1990, on reading skills for academic and professional purposes (Rivera et al., 2017), at present the focus has shifted towards oral skills in the academic and professional contexts. Yet, Cuban universities still fail to achieve the desired level in the domain of communicative competence, and the level of proficiency in English of Cuban students entering higher education remains low and heterogeneous (Rivera et al., 2016; MES, 2013). In addition, the level of motivation towards language learning tends to be low, and the students lack awareness of the need for English as a study and work tool.

\section{Research objectives and methodology}

The current research explores how Cuban language learners and teachers perceive the growing importance of English in today's higher education in Cuba. Data were collected by means of a questionnaire conducted at Universidad de Oriente in Santiago de Cuba in December 2017. The rationale to choose Universidad de Oriente is that this institution is the leading university in the eastern part of Cuba, and one of the main universities nationwide.

This study intends to answer the following research question: How do language learners and language teachers in Cuba perceive the growing importance of English in their higher education? In order to explore this question, two different areas of research were selected: English language students and their lecturers on the one hand, and Engineering students and their lecturers on the other hand. Whereas the former group was expected to take a more positive attitude towards English, the latter group was expected to take a less positive attitude or to have a lower level of motivation to learn English as their perceived need of English might be lower. That is, English may not be perceived as a top priority for many Cubans in their daily work context. Another hypothesis referred to age. Younger learners or users of English were expected to have more positive attitudes than the older generation as the latter had grown up in a different context in which English was not needed. Besides, many of these experienced lecturers had learned Russian instead of English, a language they are less acquainted with, while younger people might be more convinced of the need to learn English.

The data were obtained by means of a questionnaire, which was set up in Spanish. Since it was not feasible to pilot the questionnaire at Universidad de Oriente, it was conducted at the University of Antwerp with a group of Spanish-speaking students from various countries in Latin America, who also provided useful feedback. Both universities are involved in a transversal project set up by the Flemish Interuniversity Council VLIR-UOS (http://www.vlir-uos.be) with the aim to enhance capacity building in Cuba. The focus of 
the present programme is on English language learning, teaching and testing in Cuban higher education.

Due to persistent problems related to the internet in Cuba and the fact that Cubans are generally not familiar with completing online forms, the questionnaire was paper-based (see Appendix). This also explains why the questionnaire was completed by a relativey small sample of respondents: 20 students and 10 lecturers from the English Department and 20 students and 10 lecturers from the Engineering Department. A larger sample would not have proven to be feasible in the given circumstances.

The questionnaire consisted of multiple choice questions relating to the respondents' personal profile (1), their perceived need of English (2), English courses taken (3), the place where these courses were taken (4), the participants' perceived level of English (5), standardized exams taken in English (6), and their familiarity with the CEFR (7). The final question was an open-ended question in which respondents were asked to make associations with English (8). The intended purpose of this item was to elicit personal and creative responses instead of restraining responses to fixed alternatives.

\section{Discussion}

The questionnaire revealed that the respondents' attitudes towards English are overwhelmingly positive. While $90 \%$ of the Engineering students considered English as very important and the remaining $10 \%$ considered it as important, all Language students, their lecturers and the Engineering lecturers perceived English as very important for educational and professional prospects. The hypothesis was therefore rejected in that no relevant differences could be observed between the English language students and their lecturers on the one hand, and the Engineering students and their lecturers on the other hand. Age did not appear to be significant either. Language and Engineering students from all academic years as well as young lecturers (with 10-15 years of experience at the university) and experienced lecturers (with more than 20 years of experience at the university) agreed on the relevance of English language in this new context of Cuban higher education.

In spite of these positive attitudes towards English language learning, 70\% of the Language students and $60 \%$ of the Engineering students admitted that they had never enrolled in English language courses. In addition, $50 \%$ of the students from both areas stated to have learnt English without having attended any formal courses. This may be due to limited availability of language courses, high costs of private language tutors or lack of time. On the other hand, $40 \%$ of the Language lecturers and $50 \%$ of the Engineering lecturers, regardless of age, had taken English courses during and after university studies. Therefore, 
it might be assumed that although students recognize the importance of English, they do not take steps towards formal English training unless they are certain they will need the language after university graduation.

Regarding the perceived level of English, respondents tended to overrate their ability to communicate in English. Based on the CEFR descriptors, most Language students and lecturers rated their level of English as $\mathrm{C} 1$ or $\mathrm{C} 2$, whereas their actual level is more likely to be within the B1-B2 range, particularly in the case of the students. Besides, many language lecturers may not be 'proficient users' (C1-C2) of English either, in spite of the fact that many of them have taken the Teaching Knowledge Test certified by the British Council (Radio Cadena Agramonte, 2017). The Engineering students and lecturers overrated themselves as well, as most of them (lecturers as well as students) rated their proficiency as B2, whereas their actual level is generally lower. Yet, it may be difficult to establish an accurate range, as most respondents have never taken a standardized language proficiency test that certifies their level of English. Moreover, a very low percentage of the participants is actually familiar with the CEFR, even though the Cuban Ministry of Higher Education has adopted the CEFR as its official standard. Concerning the final question, English is most commonly associated with communication, scientific research, bibliography, academic mobility, professionalism, traveling and free-time activities. Links to the United States or its policy towards Cuba are strikingly absent in the respondents' associations.

The findings are in line with results from a large-scale study carried out at the University of Antwerp, which revealed that lecturer and student attitudes towards English are largely positive (van Splunder, 2014). It should be noted that the participants in Antwerp were more acquainted with English than their counterparts in Santiago. Moreover, their level of English was considerably higher (B2 is required for incoming students, C1 for teaching purposes).

\section{Conclusion}

Whereas in the previous decades, English was commonly associated with the United States or with US imperialism, this is hardly the case in today's Cuba, in which learning English has become a top priority. Although the sample was relatively small, this research demonstrates that attitudes towards English are largely positive as the language is associated with globalization and educational and professional prospects in Cuban higher education. In other words, English means access to the world, not just to the United States.

In contrast to earlier observations, the level of motivation towards learning English did not appear to be low, and the students did not appear to lack awareness of the need for English as a study and work tool. However, the level of English remains generally low, a fact which 
most respondents did not appear to be aware of. Moreover, from a more general perspective, it should be noted that access to English remains limited in Cuba.

As a follow up to this research, a larger-scale online questionnaire should be administered, on condition that improved internet facilities are available. Moreover, it would be relevant to conduct interviews or focus groups to analyse the attitudes in more detail to find out why they are so positive. At the same time, it could be significant to find out why negative attitudes are strikingly absent, even with the older generation. It should be considered to broaden the scope of research, and to focus on other stakeholders, such as the Ministry of Higher Education. Finally, it may be relevant to study English language attitudes in areas other than higher education, such as tourism or business, and areas in which English is not commonly used. English may mean access to the world, but it remains an open question what this implies for groups of people such as farmers whose life and work is limited to a Cuban context, and who apparently do not participate in globalization.

\section{References}

Crystal, D. (2003). English as a Global Language. Second edition. Cambridge: Cambridge University Press.

Council of Europe. (2001). Common European framework of reference for languages: learning, teaching, assessment.Cambridge. Cambridge University Press.

Dembicz, K. (2017). Cubans: a Vulnerable Society? Journal of American Studies, 17, 109118.

Dewey, M. (2007). English as a Lingua Franca and Globalization: An Interconnected Perspective. International Journal of Applied Linguistics, 17(3), 332-354.

English Proficiency Index. (n.d.). Retreived December 22, 2017, from Education First, www.ef.com/epi.

Fishman, J.A. (2006). Language Policy and Language Shift. In T. Ricento (ed.) An Introduction to Language Policy. Theory and Method. London: Blackwell, 311-328.

Grabendorff, W. (2017). Cuba: The Challenges of Change. Pensamiento Propio. Edición especial a cargo de Andrés Serbin, 22, 33-56.

Ministerio de Educación Superior. (2013). Documento base sobre el perfeccionamiento de la enseñanza del idioma inglés en las universidades cubanas. Aprobado por el Consejo de Dirección del Ministerio de Educación Superior, diciembre.

Pennycook, A. (2010). English and Globalization. In J. Maybin and J. Swann (eds.) The Routledge Companion to English Language Studies. London: Routledge.

Pignatelli, B. (2016, February 27). English Language learning in Cuba. Havana Times. Retreived from http://www.havanatimes.org/?p=117059.

Pope, C. \& Finn, J. C. (2017). Editors' Introduction: Geographies of Contemporary Cuba. Human Geography, 10(3), 1-6. 
Radio Cadena Agramonte (2017, June 22). Cuba da prioridad a superación de docentes en idioma inglés. Retreived from http://www.cadenagramonte.cu/articulos/ver/71090.

Rivera Pérez, S., Torres García, M., \& Estrada Rodríguez, P. (2017). Instrumentación de la estrategia de perfeccionamiento del inglés en las universidades del Ministerio de Educación Superior (MES). Congreso Universidad, 6(6), 73-89. Retrieved from http://www.congresouniversidad.cu/revista/index.php/rcu/article/view/976.

van Splunder, F. (2014). Negotiating Multilingualism in Flemish Higher Education. In J.W. Unger, M. Krzyżanowski and R. Wodak (eds.) Multilingual Encounters in Europe's Institutional Spaces. London: Bloomsbury, 221-242.

Wächter, B. (2014). The European map of English-taught programmes in 2014: Results of a new ACA study. Paper presented at the ACA, Brussels, 4 December 2014.

\section{Appendix: Questionnaire}

\section{Cuestionario}

El siguiente cuestionario se enfoca en las actitudes hacia el aprendizaje del idioma inglés en la enseñanza superior en Cuba, particularmente en la Universidad de Oriente. Agradecemos su colaboración.

1. Actualmente, usted es

Estudiante (Facultad ; Año académico

Profesor (Facultad. ; Años de experiencia como profesor en la universidad......)

2. ¿Cómo califica la importancia del idioma inglés para su carrera profesional?

Muy importante

Importante

Poco importante

Nada importante

3. ¿Ha tomado cursos de inglés? (Es posible marcar más de una opción)

Sí, antes de entrar a la universidad

Sí, durante la universidad

Sí, después de terminar la universidad

No, nunca he tomado cursos de inglés

4. ¿Dónde ha tomado los cursos de inglés? (Es posible marcar más de una opción)

En instituciones estatales

En instituciones no estatales

Autodidacta

Ninguna de estas alternativas 
5. ¿Cuál considera que es su nivel de comunicación en inglés?

No me puedo comunicar en inglés

Básico. Puedo relacionarme de forma elemental, siempre que la otra persona hable despacio, con claridad y esté dispuesta a cooperar.

Intermedio Bajo. Puedo comunicarme de manera sencilla sobre temas de mi interés personal o que me son familiares, y a la hora de realizar tareas simples y diarias, que requieran solo información sobre cuestiones que son conocidas o habituales para mí.

Intermedio Alto. Puedo comunicarme con un grado suficiente de fluidez y naturalidad, de modo que la conversación se realice sin esfuerzo por parte de ninguno de los interlocutores.

Avanzado. Puedo usar el idioma de forma flexible y efectiva para fines sociales, académicos y profesionales.

6. ¿Ha hecho un examen de idioma para saber su nivel de inglés?

Sí, TOEFL

Sí, IELTS

Sí, otro examen (Indique cuál........................................)

No, nunca

7. ¿Está familiarizado con la escala de dominio de la lengua del Marco Común Europeo de Referencia (en inglés Common European Framework of Reference)?

- Sí

No

8. ¿Cón que asocia el idioma inlgés? Escriba solo cinco palabras. 